Vol. 1 No.2, September 2020

P-ISSN: 2746-0967, E-ISSN: 2721-656X

\title{
Urgensi Penerapan Analisis Dampak Lingkungan (AMDAL) sebagai Kontrol Dampak terhadap Lingkungan di Indonesia
}

Satria Sukananda ${ }^{1}$, Danang Adi Nugraha ${ }^{2}$

Kantor Wilayah Badan Pertanahan Nasional Provinsi Kepulauan Riau1,

Kantor Pertanahan Kota Metro Provinsi Lampung ${ }^{2}$

E-mail: satria.sukananda@atrbpn.go.id¹ danang.adinugraha6@gmail.com²

\section{INFO ARTIKEL}

Perjalanan Artikel:
Artikel Dikirimkan oleh
penulis: 06-04-20
Artikel Direview: 08-04-20
Artikel Direvisi: 02-06-20
Artikel Diterima atau
Dipublikasikan: 24-08-20
DOI: 10.18196/jphk.1207

\section{Pendahuluan}

Lingkungan Hidup sebagai anugerah Tuhan Yang Maha Esa kepada rakyat dan tetap menjadi sumber dan penunjang hidup bagi rakyat dan bangsa Indonesia serta makhluk hidup lainnya demi kelangsungan dan peningkatan kualitas hidup itu sendiri. ${ }^{1}$

\begin{abstract}
ABSTRAK
Penelitian ini dilakukan untuk mengetahui bagaimana urgensi penerapan Analisis Dampak Lingkungan (AMDAL) sebagai kontrol dampak terhadap lingkungan di Indonesia. Terkait dengan perlindungan dan pengelolaan lingkungan hidup, faktor utama yang harus menjadi fokus perhatian adalah terkait dengan perizinan, karena faktor perizinan dapat dijadikan pegangan bagi pelaku usaha yang akan mengelola lingkungan. Perizinan lingkungan dikaitkan dengan keharusan memperoleh Analisis Mengenai Dampak Lingkungan (AMDAL). Statute approach dipergunakan dalam penelitian hukum normatif ini. Hasil penelitian menunjukkan Kedudukan AMDAL dalam pengelolaan Lingkungan hidup sangat penting dan strategis karena merupakan instrumen pencegahan pencemaran lingkungan yang menentukan mutu lingkungan melalui mekanisme pengujian dokumen seperti AMDAL dan UKL-UPL. Selanjutnya penerapan AMDAL juga menjadi sistem yang menjaga stabilitas tujuan perusahaan.
\end{abstract}

Kata Kunci: Analisis Dampak Lingkungan, Pencegahan Pencemaran Lingkungan, Pengelolaan Lingkungan Hidup.

${ }^{1}$ Muchammad Taufiq (2011) Kedudukan dan Prosedur Amdal Dalam Pengelolaan Lingkungan Hidup, Jurnal Wiga. 2(2), hal 1 
Undang-Undang Dasar Republik Indonesia Tahun 1945 sebagai landasan konstitusional mewajibkan agar sumber daya alam dipergunakan untuk sebesarbesar kemakmuran rakyat. Kemakmuran rakyat tersebut haruslah dapat dinikmati generasi masa kini dan generasi masa depan secara berkelanjutan. Pembangunan sebagai upaya sadar dalam mengelola dan memanfaatkan sumber daya alam untuk meningkatkan kemakmuran rakyat, baik untuk mencapai kemakmuran lahir maupun untuk mencapai kepuasan batin. Sehingga pengunaan sumber daya alam harus selaras, serasi dan seimbang fungsi lingkungan hidup. ${ }^{2}$

Indonesia dikenal sebagai negara dengan potensi sumber daya alam yang sangat besar, dengan potensi sumber daya alam yang besar tersebut menjadi suatu keharusan bagi kita semua untuk menjaga dan melindunginya, sehingga proses pembangunan maupun kegiatan usaha suatu perusahaan tidak mengakibatkan suatu krisis lingkungan hidup. Krisis lingkungan adalah ancaman masa depan umat manusia yang mana pertambahan kerusakan lingkungan telah mencapai dimensi regional, global dan terus berdampak besar. Pemanasan global yang semakin meningkat mengakibatkan perubahan iklim sehingga memperparah penurunan kualitas lingkungan hidup saat ini, karena itu perlu dilakukan perlindungan dan pengelolaan lingkungan hidup yang baik. Pengelolaan, penggunaan maupun pemanfaatan sumber daya alam harus diseimbangkan dengan lingkungan hidup, sehingga diperlukan suatu kebijaksanaan nasional pengelolaan lingkungan hidup yang komprehensif. Hal ini sejalan dengan konsep studi lingkungan hidup yang mengkhususkan pada ilmu hukum, dengan objek hukumnya adalah tingkat perlindungan sebagai kebutuhan hidup. ${ }^{3}$

Bertalian dengan perlindungan dan pengelolaan lingkungan hidup, faktor utama yang harus menjadi fokus perhatian adalah terkait dengan perizinan, karena faktor perizinan dapat dijadikan pegangan bagi pelaku usaha yang akan mengelola lingkungan. Perizinan lingkungan dikaitkan dengan keharusan memperoleh AMDAL (Ananlisis Mengenai Dampak Lingkungan) sebagai instrumen pencegahan pencemaran lingkungan dimana asas ini telah dituangkan dalam bentuk produk hukum, sehingga menjadi kewajiban yang harus dipatuhi oleh setiap orang di Indonesia, artinya untuk terbitnya atau disetujuinya suatu izin lingkungan hendaknya harus diperoleh lebih dahulu AMDAL. Sejalan dengan pandangan Suparto Wijoyo, bahwa berkaitan dengan perizinan lingkungan terpadu seharusnya bertumpu pada pada prinsip-prinsip prosedur administratif perizinan lingkungan menurut "good environmental governance". ${ }^{4}$

\footnotetext{
${ }^{2}$ Ibid.

${ }^{3}$ St. Danusaputro (1998) Hukum Lingkungan, Bandung: Buku.I Bina Cipta, hal. 46

${ }^{4}$ Suparto Wijoyo (1999) Penyelesaian Sengketa Lingkungan, Surabaya: Airlangga University Press, hal. 328-329.
} 
Menjadi suatu paradoks ketika pada kondisi saat ini demi mendorong masuknya investasi ada wacana untuk mereduksi keberadaan AMDAL sebagai sarana penjagaan terhadap rencana usaha atau kegiatan usaha supaya tidak memberikan dampak buruk pada lingkungan. Wacana tersebut muncul karena AMDAL dianggap rumit dan mempersulit para investor masuk di Indonesia.

Salah satu contoh pengreduksian fungsi AMDAL adalah lahirnya Peraturan Pemerintah Nomor 24 Tahun 2018 tentang Pelayanan Perizinan Berusaha Terintegrasi Secara Elektronik. Berdasarkan peraturan ini pelaku usaha dapat mengantongi izin usaha hanya dengan komitmen sebagaimana diatur di dalam Pasal 20 yang menyatakan:

Pelaksanaan Perizinan Berusaha meliputi:

a. Pendaftaran;

b. Penerbitan Izin Usaha dan penerbitan Izin komersial atau Operasional berdasarkan Komitmen;

c. Pemenuhan Komitmen Izin Usaha dan pemenuhan Komitmen Izin Komersial atau Operasional;

d. Pembayaran biaya;

e. Fasilitas;

f. Masa belaku; dan

g. Pengawasan.

Selanjutnya Pasal 32 yang menyatakan:

(1) Lembaga OSS (Online Single Submission) menerbitkan Izin Usaha berdasarkan Komitmen kepada:

a. Pelaku usaha yang tidak memerlukan prasarana untuk menjalankan usaha dan/atau kegiatan sebagaimana dimaksud dalam Pasal 31 ayat (2) huruf a dan;

b. Pelaku usaha yang memerlukan prasarana untuk menjalankan usaha dan/atau kegiatan dan telah memiliki prasarana sebagaimana dalam Pasal 31 ayat (3) huruf a.

(2) Lembaga OSS menerbitkan Izin Usaha berdasarkan Komitmen kepada Pelaku Usaha yang memerlukan prasarana untuk menjalankan usaha dan/atau kegiatan tapi belum memiliki atau menguasai prasarana setelah Lembaga OSS menerbitkan:
a. Izin lokasi;
b. Izin lokasi perairan;
c. Izin lingkungan; dan atau
d. IMB. 
Sebagaimana telah dijelaskan Peraturan Pemerintah Nomor 24 Tahun 2018 tentang Pelayanan Perizinan Berusaha Terintegrasi Secara Elektronik jelas bertentangan dengan semangat UUPPLH yang menyatakan bahwa setiap usaha dan/atau kegiatan yang berdampak penting ${ }^{5}$ terhadap lingkungan hidup wajib memiliki Izin lingkungan yang berbasis AMDAL.

Tanpa mempertimbangkan besar-kecilnya risiko kerusakan. Apabila memang akan dilakukan evaluasi terhadap pengunaan AMDAL dengan berbagai mekanisme perubahan kebijakan sistem perizinan yang nantinya diberlakukan tentunya seharusnya AMDAL tetap menjadi prioritas kunci syarat diperolehnya izin berusaha, karena apabila sebaliknya AMDAL bukan lagi menjadi prioritas sebagaimana yang disebut penulis sebagai wacana untuk mereduksi keberadaan AMDAL hal ini dapat mempercepat proses kerusakan ekologi dan sosial, wacana ini tentu menggambarkan bahwa kemajuan ekonomi dengan mendorong masuknya investasi mengabaikan ekologi yang ada, atau dapat dikatakan bahwa demi masuknya investasi maka silahkan melakukan pengrusakan terhadap lingkungan, hal ini merupakan pemahaman yang sangat keliru. Analisis Mengenai Dampak Lingkungan atau AMDAL adalah sebuah upaya untuk mengurangi pengaruh negatif dan resiko pada tingkat yang mungkin terjadi serta mengelola resiko tersebut melalui mekanisme dan sistem hukum lingkungan. Kata kunci dari Analisis Mengenai Dampak Lingkungan yang lebih dikenal dengan istilah AMDAL ada pada kata "analisis ilmiah". ${ }^{6}$ Adanya Peraturan Pemerintah No. 27 Tahun 2012 tentang Izin Lingkungan, yang merupakan pelaksanaan dari UU No. 32 Tahun 2009 tentang Perlindungan dan Pengelolaan Lingkungan Hidup (UUPPLH) mendorong penyesuaian dari peraturan perundangan yang ada sebagai perkembangan baru yang masih perlu dibahas serta menjadi diskursus yang penting yaitu terkait urgensi AMDAL untuk menjadi pembentuk hukum lingkungan. ${ }^{7}$

Berkaca pada Peraturan Pemerintah Nomor 24 Tahun 2018 tentang Pelayanan Perizinan Berusaha Terintegrasi Secara Elektronik yang secara jelas mereduksi keberadaan AMDAL, sudah saatnya hukum diupayakan secara progresif dan hukum mesti tiba pada radikalitas pembongkaran pada asumsi-asumsi hukum yang selama ini dianggap mapan, yaitu pada kontekstualitas kajian subjek hukum yang tidak semestinya bersikap abai terhadap ekologi. ${ }^{8}$ Ketika hukum bergeser untuk konteks

5 Peraturan Menteri Lingkungan Hidup dan Kehutanan Republik Indonesia Nomor: P.38/MENLHK/SETJEN/KUM.1/7/2019 tentang Rencana Usaha dan/atau Kegiatan Yang Wajib Memiliki Analisis Dampak Lingkungan Hidup, dampak penting adalah perubahan lingkungan hidup yang sangat mendasar yang diakibatkan oleh suatu Usaha dan/atau Kegiatan.

6 M.Daud Silalahi dan Kristianto (2016) Perkembangan Pengaturan amdal di Indonesia, Bandung: Keni Media, hal. 1.

${ }^{7}$ Ibid, hlm. 11.

${ }^{8}$ Muhammad Rustamaji (2017) Pilar-Pilar Hukum Progresif, Menyelami Pemikiran Satjipto Rahardjo, Yogyakarta: Thafa Media, hal. 18. 
kehidupan sejagat, maka manusia bukan lagi menjadi titik sentral satu-satunya, karena pada spektrum yang lebih luas, hukum difungsikan tidak hanya untuk memeriksa keadilan, tetapi sudah menghasilkan keadilan bahkan keadilan jenis baru (new kind of justice), yaitu keadilan bagi lingkungan atau ekologi. ${ }^{9}$ Oleh karena itu, adanya AMDAL sebagai sarana pemantauan atau sebagai alat kontrol dan koreksi terhadap pelaksanaan suatu kegiatan usaha yang dilakukan perusahaan maupun dalam pelaksanaan operasi proyek, serta untuk mencapai atau terlaksananya perlindungan terhadap lingkungan, bahkan guna menghasilkan keadilan bagi ekologi.

Berdasarkan latar belakang tersebut diatas, penulis tertarik untuk mengkaji lebih lanjut mengenai pentingnya AMDAL untuk terwujudnya keadilan bagi ekologi di Indonesia yang dituliskan dalam sebuah bentuk penulisan hukum yang berjudul “Urgensi Analisis Dampak Lingkungan (AMDAL) Sebagai Kontrol Dampak Terhadap Lingkungan Di Indonesia".

Bertitik tolak dari uraian dalam latar belakang di atas, maka perumusan masalah dalam penelitian ini yaitu bagaimana urgensi penerapan Analisis Dampak Lingkungan (AMDAL) sebagai kontrol dampak terhadap lingkungan di Indonesia?.

\section{Metodologi}

Penelitian ini merupakan penelitian hukum normatif dengan menggunakan studi kepustakaan yaitu penelitian hukum yang meletakkan hukum sebagai sebuah banguan sistem norma. ${ }^{10}$ Adapun pencarian bahan didasarkan pada bahan hukum yang telah ada baik dalam bentuk peraturan perundang-undangan maupun karya tulis seperti buku-buku ataupun artikel lain yang terdapat dalam situs internet yang relevan dengan objek penelitian ini.11 Penelitian hukum normatif ini digunakan dalam memahami urgensi penerapan Analisis Dampak Lingkungan (AMDAL) sebagai kontrol dampak terhadap lingkungan di Indonesia. ${ }^{12}$

Penulisan penelitian ini menggunakan pendekatan statute approach. Statute approach adalah pendekatan melalui peraturan perundang-undangan di mana penelitian dilakukan dengan cara menelaah undang-undang regulasi yang bersangkut paut dengan isu hukum urgensi penerapan Analisis Dampak Lingkungan (AMDAL) sebagai kontrol dampak terhadap lingkungan di Indonesia baik menurut

${ }^{9}$ Ibid, hlm. 19.

${ }^{10}$ Mukti Fajar Nur Dewata dan Yulianto Achmad (2010) Dualisme Penelitian Hukum Normatif \& Empiris, Yogyakarta: Pustaka Pelajar, hal. 34

${ }^{11}$ Amiruddin dan H. Zainal Asikin (2003) Pengantar Metode Penelitian Hukum, Jakarta: PT. Raja Grafindo Persada, hal. 118.

${ }^{12}$ Peter Mahmud Marzuki (2005) Penelitian Hukum Normatif, Cetakan I, Jakarta: Kencana, hal.93 
Undang-Undang Nomor 32 Tahun 2009 tentang Perlindungan dan Pengelolaan Lingkungan Hidup (UUPPLH), Peraturan Pemerintah No. 27 Tahun 2012 tentang Izin Lingkungan, yang merupakan pelaksanaan dari UU No. 32 Tahun 2009 tentang Perlindungan dan Pengelolaan Lingkungan Hidup (UUPPLH) dan Peraturan Pemerintah Nomor 24 Tahun 2018 tentang Pelayanan Perizinan Berusaha Terintegrasi Secara Elektronik.13

Penelitian ini menggunakan bahan hukum kepustakaan yang dapat berupa peraturan perundang-undangan, dokumen, buku-buku, laporan, arsip, dan literatur yang berkaitan dengan masalah yang diteliti. Bahan hukum yang akan digunakan dalam penelitian ini adalah:

\subsection{Bahan Hukum Primer}

Bahan hukum primer yaitu bahan-bahan hukum pokok yang mengikat. Dalam penilitian ini, digunakan bahan hukum primer berupa:

a. Undang-Undang Dasar Republik Indonesia tahun 1945;

b. Undang-Undang Nomor 32 Tahun 2009 tentang Perlindungan dan Pengelolaan Lingkungan Hidup;

c. Peraturan Pemerintah Nomor 27 Tahun 2012 tentang Izin Lingkungan;

d. Peraturan Pemerintah Nomor 24 Tahun 2018 tentang Pelayanan Perizinan Berusaha Terintegrasi Secara Elektronik;

e. Peraturan Menteri Lingkungan Hidup dan Kehutanan Republik Indonesia Nomor: P.38/MENLHK/SETJEN/KUM.1/7/2019 tentang Rencana Usaha dan/atau Kegiatan Yang Wajib Memiliki Analisis Dampak Lingkungan Hidup.

\subsection{Bahan Hukum Sekunder}

Bahan hukum sekunder yaitu bahan-bahan hukum yang mendukung dan memperjelas bahan hukum primer yang berupa dokumen-dokumen resmi, meliputi karya tulis, buku-buku teks, jurnal-jurnal hukum dan komentarkomentar atas putusan pengadilan.

\subsection{Bahan non-hukum}

Bahan yang memberikan penjelasan maupun petunjuk terhadap bahan hukum primer maupun sekunder yang telah ada seperti Kamus Besar Bahasa Indonesia dan lain sebagainya yang digunakan untuk mencari istilah-istilah dalam rangka menjelaskan hal-hal yang digunakan dalam bahan hukum primer maupun bahan hukum sekunder.

\footnotetext{
${ }^{13}$ Soetandyo Wignjosoebroto (2013) Hukum, Konsep dan Metode, Malang: Setara Press, hal.
} $67-71$. 
Teknis pengumpulan data yang akan digunakan dalam penelitian hukum ini adalah studi kepustakaan yang terbatas pada penggunaan dokumen dan bahan pustaka. Pengumpulan data dilakukan dengan cara mengumpulkan data-data tertulis yang berkaitan dengan masalah yang diteliti.

Terkait dengan metode analisis bahan hukum yang digunakan dalam penelitian ini menggunakan metode deduktif. Yaitu berpangkal dari prinsip-prinsip dasar kemudian menghadirkan objek yang hendak diteliti, dengan kata lain, berpangkal dari prinsip-prinip umum menuju prinsip-prinip khusus. ${ }^{14}$

\section{Analisis dan Hasil}

\subsection{Urgensi Penerapan AMDAL Sebagai Kontrol Dampak Terhadap Lingkungan Di Indonesia.}

\subsubsection{Perkembangan Pengaturan AMDAL}

AMDAL untuk pertama kalinya lahir dengan dicetuskannya Undang-Undang lingkungan hidup yang disebut National Environmental Policy Act (NEPA) oleh Amerika Serikat pada Tahun 1969. NEPA mulai berlaku pada tanggal 1 Januari 1970. Pasal 102 ayat (2) (C) dalam undang-undang ini menyatakan bahwa semua usulan legislasi dan aktivitas pemerintah federal yang besar diperkirakan akan mempunyai dampak penting terhadap lingkungan diharuskan disertai laporan Enviromental Impact Assesment (Analisis Dampak Lingkungan).

AMDAL dengan cepat menyebar di negara-negara maju yang kemudian disusul oleh negara berkembang dengan banyaknya pihak yang telah merasakan bahwa AMDAL adalah alat yang mampu untuk menghindari terjadinya kerusakan lingkungan yang lebih parah akibat aktivitas manusia. Dengan mengacu pada NEPA, maka untuk pertama kalinya pada tahun 1982 Indonesia mencetuskan UndangUndang Lingkungan Hidup Nomor 4 Tahun 1982 tentang Ketentuan-Ketentuan Pokok Pengelolaan Lingkungan Hidup. Undang-undang ini merupakan langkah awal Indonesia untuk menjadikan pembangunan berwawasan lingkungan. Pasal 16 UULH Nomor 4 Tahun 1982 menyatakan bahwa setiap rencana yang diperkirakan mempunyai dampak penting terhadap lingkungan hidup wajib dilengkapi dengan analisis mengenai dampak lingkungan yang pelaksanaannya diatur dengan peraturan pemerintah. ${ }^{15}$

Untuk menindaklanjuti pelaksanaannya, dikeluarkanlah Peraturan Pemerintah Nomor 29 Tahun 1986 tentang Analisis Mengenai Dampak Lingkungan dalam Lembaran Negara Tahun 1986 Nomor 42 Tambahan Lembaran Negara Nomor

${ }^{14}$ Mukti Fajar Nur Dewata dan Yulianto Achmad (2010) Dualisme Penelitian Hukum...op.cit.,

${ }^{15}$ Program Studi Kesehatan Masyarakat Fakultas Farmasi dan Ilmu Kesehatan Universitas Sari Mutiara, Analisis Dampak Lingkungan, hlm 3 
3338. Isinya menyatakan bahwa AMDAL dimaksudkan sebagai bagian dari studi kelayakan pembangunan suatu rencana usaha dan/atau kegiatan. Peraturan Pemerintah Nomor 29 Tahun 1986 kemudian dicabut dan diganti dengan Peraturan Pemerintah Nomor 51 Tahun 1993 yang kemudian diganti lagi dengan Peraturan Pemerintah Nomor 27 Tahun 1999 tentang Analisis Mengenai Dampak Lingkungan. Semenjak itulah semakin banyak munculnya peraturan perundang-undangan lain mengenai AMDAL, salah satu yang tergolong sangat penting untuk menentukan bentuk kajian lingkungan yang akan dilakukan adalah Peraturan Menteri Lingkungan Hidup dan Kehutanan Republik Indonesia Nomor: P.38/MENLHK/SETJEN/KUM.1/7/2019 tentang Rencana Usaha dan/atau Kegiatan Yang Wajib Memiliki Analisis Dampak Lingkungan Hidup.

\subsubsection{Kedudukan AMDAL dalam Pengelolaan Lingkungan Hidup}

Secara umum kegunaan AMDAL adalah:

1. Memberikan informasi secara jelas mengenai suatu rencana usaha, berikut dampak-dampak lingkungan yang akan ditimbulkannya;

2. Menampung aspirasi, pengetahuan dan pendapat penduduk khususnya dalam masalah lingkungan sewaktu akan didirikannya suatu usaha atau kegiatan perindustrian;

3. Menampung informasi setempat yang berguna bagi pemrakarsa dan masyarakat dalam mengantisipasi dampak dan mengelola lingkungan. ${ }^{16}$

Selanjutnya dalam usaha menjaga kualitas lingkungan, secara khusus AMDAL berguna dalam hal:

1. Mencegah agar potensi sumber daya alam yang dikelola tidak rusak, terutama sumber daya alam yang tidak dapat diperbaharui;

2. Menghindari efek samping dari pengelolahan sumber daya terhadap sumber daya alam lainnya, proyek-proyek lain, dan masyarakat agar tidak timbul pertentangan-pertentangan;

3. Mencegah terjadinya perusakan lingkungan akibat pencemaran sehingga tidak menggangu kesehatan, kenyamanan, dan keselamatan rakyat.

4. Agar dapat diketahui manfaatnya yang berdaya guna dan berhasil guna bagi bangsa, negara dan masyarakat.

Tugas utama dari AMDAL adalah memilah perubahan-perubahan yang ditimbulkan oleh aktifitas pembangunan yang ditawarkan agar menjadi bagian dari siklus alam. Satu eksperimen yang terkendali dapat dilakukan untuk membandingkan perubahan dalam parameter kualitas lingkungan. Satu sistem

16 Ibid. 
disiapkan sebagai pengontrol. Fungsi ini dapat dibebankan kepada kawasan lindung. Sedangkan sistem alam lainnya yaitu di kawasan budi daya berlangsung aktifitas pembangunan. Pengkajian AMDAL yang terpenggal-penggal atau mengabaikan satu komponen tertentu dapat menyebabkan terganggunya kestabilan komponen yang lain. ${ }^{17}$

AMDAL dimaksudkan untuk pembangunan, perbaikan pembangunan, perbaikan pembangunan diidentifikasi dengan AMDAL. AMDAL merupakan salah satu alat pembangunan berkelanjutan sebagai sarana pengambilan keputusan di tingkat pelaksanaan usaha. Seharusnya amdal sebagai salah satu motor pembangunan, namun jika dalam pelaksanaanya salah langkah maka proses AMDAL bisa menjadi beban. ${ }^{18}$

Kedudukan dan fungsi AMDAL bagi suatu perusahaan juga dapat memberikan rambu-rambu pada tujuan perusahaan. Menurut Bryant Maynard Jr dan Susan E Mehrtens dalam perspektif ilmu hukum perusahaan, tujuan perusahaan tidak hanya berfokus untuk mencari keuntungan (profit), namun juga menciptakan kesejahteraan sosial (people) dan melestarikan lingkungan hidup (planet). ${ }^{19}$ Selanjutnya Elkinston Elkinston menegaskan bahwa perusahaan yang baik tidak hanya memburu keuntungan ekonomi belaka (profit). Melainkan pula, memiliki kepedulian terhadap kelestarian lingkungan (planet) dan kesejahteraan masyarakat (people).

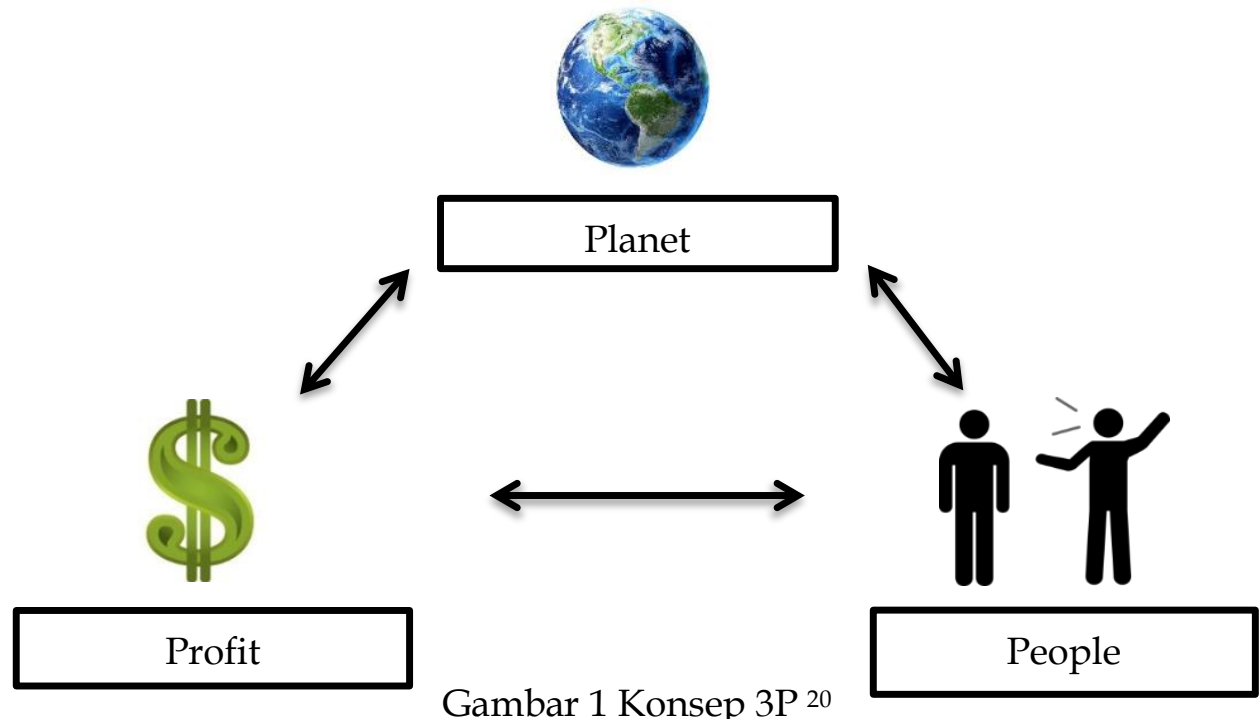

${ }^{17}$ Ibid.

${ }^{18}$ Ninik Suparni (1994) Pelestarian Pengelolaan dan Penegakan Hukum Lingkungan, Jakarta: Sinar Grafika, hal. 119

${ }^{19}$ Satria Sukananda (2019) Pertanggungjawaban Perusahaan Terhadap Tidak Terlaksananya Kewajiban Tanggung Jawab Sosial Perusahaan (Corporate Social Responsibility) di Indonesia, Yogyakarta: Tesis Program Pascasarjana Magister Ilmu Hukum Fakultas Hukum Universitas Islam Indonesia, hal. 1

${ }^{20}$ www.ekatjicptafoundation.org, Dikutip dari Edi Suharto (2010) CSR \& Comdev investasi Kreatif Perusahaan di Era Globalisasi, Bandung: Alfabeta, hal 5 


\subsubsection{Analisis Dampak Lingkungan (AMDAL) Dalam Mekanisme Sistem Perizinan di Indonesia}

AMDAL sebagai salah satu persyaratan dalam izin lingkungan merupakan studi aktivitas yang tersusun secara sistemik dan ilmiah dengan menggunakan teknik pendekatan yan bersifat interdisiplener bahkan multidislipliner, maka studi tersebut haruslah tersusun secara runtut dan komprehensif-integral (terpadu-lintas sektoral). ${ }^{21}$

AMDAL dalam mekanisme sistem perizinan berdasarkan Undang-Undang Nomor 32 Tahun 2009 tentang Perlindungan dan Pengelolaan Lingkungan Hidup (UUPLH):

1. AMDAL sebagai informasi yang harus terbuka bagi masyarakat (BAB VIII, Pasal 62 UUPPLH);

2. AMDAL sebagai alat prediksi kemungkinan terjadinya dampak/ongkos;

3. AMDAL sebagai alat pemantau/RPL dan pengelolaan/RKL kegiatan;

4. AMDAL sebagai legal evidence.

Dalam konteks perizinan kegiatan usaha, AMDAL akan menjadi tolok ukur yang mendasar secara spesifik, terkait tindak lanjut perizinan usaha tersebut. maka AMDAL tiap-tiap jenis kegiatan usaha akan memiliki analisa ilmiah yang berbedabeda pula.

Berdasarkan Undang-Undang Nomor 32 Tahun 2009 tentang Perlindungan dan Pengelolaan Lingkungan Hidup (UUPPLH) AMDAL sebagai dasar pertama sistem perizinan usaha akan berpengaruh besar terhadap izin lingkungan yang akan dikeluarkan oleh Pemerintah. Kemudian akan berlanjut kepada izin usaha/kegiatan. Boleh dikatakan AMDAL adalah garda pertama penentu baik buruknya kualitas izin lingkungan dan izin kegiatan. ${ }^{22}$ Oleh karenanya jika Peraturan Pemerintah Nomor 24 Tahun 2018 tentang Pelayanan Perizinan Berusaha Terintegrasi Secara Elektronik hanya menempatkan komitmen untuk memperoleh izin usaha tanpa didahului izin linkungan yang berbasis AMDAL maka sistem kontrol terhadap pelaku usaha untuk tidak merusak lingkungan atau ekologi menjadi tidak terjelaskan dengan baik.

\subsubsection{Penyusunan Analisis Dampak Lingkungan Berdasarkan Peraturan Perundang-Undangan}

Dalam mekanisme AMDAL dikenal adanya dokumen-dokumen yang harus dipenuhi, yakni Upaya Pengelolaan Lingkungan Hidup dan Upaya Pemantauan Lingkungan Hidup (UKL-UPL), Analisis Dampak Lingkungan (ANDAL), Rencangan

${ }^{21}$ Sumadi Kamarol Yakin (2017) Analisis Mengenai Dampak Lingkungan (AMDAL) Sebagai Instrumen Pencegahan Pencemaran dan Perusakan Lingkungan, Badamai Law Journal, 2 (1) hal. 123

${ }^{22}$ Ibid. 
Pengelolaan Lingkungan (RKL) Rencana Pemantauan Lingkungan (RPL). ${ }^{23}$ Peraturan Pemerintah Nomor 24 Tahun 2018 tentang Pelayanan Perizinan Berusaha Terintegrasi Secara Elektronik menentukan bahwa pelaku usaha wajib memenuhi Komitmen Izin Lingkungan yang diterbitkan oleh Lembaga OSS dengan melengkapi Upaya Pengelolaan Lingkungan Hidup dan Upaya Pemantauan Lingkungan Hidup (UKLUPL) dan Dokumen Amdal yang dilakukan dengan sistem OSS yang terdiri dari ANDAL, RKL dan RPL berdasarkan kerangka acuan yang telah mendapatkan keputusan instansi yang berkompeten. ${ }^{24}$ ANDAL digunakan sebagai telaah yang cermat mengenai dampak suatu kegiatan. ${ }^{25}$ Pada dasarnya ANDAL bertujuan untuk menganalisa suatu kegiatan yang berpotensi memberikan dampak terhadap lingkungan, yang juga sekaligus nantinya akan menjadi salah satu poin penting dalam pengambilan keputusan terkait izin usaha suatu kegiatan. RKL adalah upaya penanganan dampak besar dan penting yang timbul sebagai akibat dari rencana kegiatan. Sedangkan RPL adalah upaya pemantauan komponen lingkungan yang terkena dampak besar dan penting sebagai akibat dari rencana kegiatan. ${ }^{26}$

Secara ilmiah prosedur pelaksanaan akan bersinggungan dengan disiplin ilmu lainnya. ini akan menjadi bukti, bahwa AMDAL memiliki metode ilmiah sendiri dalam setiap jenis kegiatan/usaha. Dalam Peraturan Pemerintah Nomor 24 Tahun 2018 tentang Pelayanan Perizinan Berusaha Terintegrasi Secara Elektronik mengamanatkan secara prosedural penyusunan dokumen AMDAL.

Pelaksanaan AMDAL menurut Peraturan Pemerintah Nomor 24 Tahun 2018 tentang Pelayanan Perizinan Berusaha Terintegrasi Secara Elektronik mengatakan bahwasanya dalam pelaksanaan AMDAL harus mengikutsertakan masyarakat yang terkena dampak dan dapat pula melibatkan pemerhati lingkungan hidup. ${ }^{27}$

Pengikutsertaan masyarakat sebagaimana dimaksud dan/atau pemerhati lingkungan melalui:

a. Pengumuman rencana usaha dan/atau kegiatan; dan

b. Konsultasi publik.

\footnotetext{
${ }^{23}$ Peraturan Pemerintah Republik Indonesia Nomor 24 Tahun 2018 tentang Pelayanan Perizinan Berusaha Terintegrasi Secara Elektronik

${ }^{24}$ Pasal 50 dan Pasal 54 ayat (3) Peraturan Pemerintah Republik Indonesia Nomor 24 Tahun 2018 tentang Pelayanan Perizinan Berusaha Terintegrasi Secara Elektronik

${ }^{25}$ Pasal 1 angka 24 Peraturan Pemerintah Republik Indonesia Nomor 24 Tahun 2018 tentang Pelayanan Perizinan Berusaha Terintegrasi Secara Elektronik. 123.

${ }^{26}$ Sumadi Kamarol Yakin, Analisis Mengenai Dampak Lingkungan (AMDAL)...Op.cit., hlm.

${ }^{27}$ Berdasarkan Peraturan Menteri Lingkungan Hidup dan Kehutanan Republik Indonesia Nomor: P.38/MENLHK/SETJEN/KUM.1/7/2019 tentang Rencana Usaha dan/atau Kegiatan Yang Wajib Memiliki Analisis Dampak Lingkungan Hidup, dampak penting adalah perubahan lingkungan hidup yang sangat mendasar yang diakibatkan oleh suatu Usaha dan/atau Kegiatan.
} 
Berdasarkan Pasal 55 ayat (5) Peraturan Pemerintah Nomor 24 Tahun 2018 tentang Pelayanan Perizinan Berusaha Terintegrasi Secara Elektronik Dalam kaitannya dengan masyarakat, Pengikutsertaan masyarakat dilakukan melalui pengumuman rencana Usaha dan/atau Kegiatan atau juga melalui konsultasi publik, pengikutsertaan masyarakat disini dilakukan sebelum Penyusunan AMDAL dibuat. Masyarakat sebagaimana yang dimaksud di atas, dalam jangka waktu 5 (lima) hari terhitung sejak pengumuman rencana usaha dan/atau kegiatan, berhak mengajukan saran, pendapat, dan tanggapan terhadap rencana Usaha dan/atau Kegiatan. ${ }^{28}$

Pelaku usaha menyusun ANDAL dan RKL-RPL berdasarkan kerangka acuan, ANDAL RKL-RPL yang telah disusun sebagaimana dimaksud diajukan kepada:29

a. Menteri yang menyelenggarakan urusan pemerintahan di bidang perlindungan dan pengelolaan lingkungan hidup melalui Komisi Penilai AMDAL Pusat, untuk kerangka acuan yang dinilai oleh Komisi Penilai AMDAL Pusat;

b. Gubernur melalui Komisi Penilai AMDAL Provinsi, untuk kerangka acuan yang dinilai oleh Komisi Penilai AMDAL Provinsi atau;

c. Bupati/walikota melalui Komisi Penilai AMDAL kabupaten/kota, untuk kerangka acuan yang dinilai oleh Komisi Penilai Kabupaten/Kota

d. Komisi Penilai AMDAL melakukan penilaian ANDAL dan RKL-RPL sesuai dengan kewenangannya.

Selanjutnya Penilai Komisi Penilai AMDAL sebagaimana dimaksud dalam Pasal 57 menyampaikan rekomendasi hasil penilaian ANDAL dan RKL-RPL kepada menteri yang menyelenggarakan urusan pemerintahan di bidang perlindungan dan pengelolaan lingkungan hidup, gubernur, atau bupati/wali kota sesuai kewenangannya. ${ }^{30}$

Rekomendasi hasil penilaian ANDAL dan RKL-RPL sebagaimana dimaksud dapat berupa: ${ }^{31}$

a. Rekomendasi kelayakan lingkungan; atau

b. Rekomendasi ketidaklayakan lingkungan.

Dalam hal rapat Komisi Penilai AMDAL menyatakan bahwa dokumen ANDAL dan RKL-RPL perlu diperbaiki, Komisi Penilai AMDAL mengembalikan dokumen ANDAL dan RKL-RPL kepada Pelaku Usaha selaku pemrakarsa untuk

28 Peraturan Pemerintah Nomor 24 Tahun 2018 tentang Pelayanan Perizinan Berusaha Terintegrasi Secara Elektronik

${ }^{29}$ Pasal 57 Peraturan Pemerintah Nomor 24 Tahun 2018 tentang Pelayanan Perizinan Berusaha Terintegrasi Secara Elektronik

${ }^{30}$ Pasal 58 Peraturan Pemerintah Nomor 24 Tahun 2018 tentang Pelayanan Perizinan Berusaha Terintegrasi Secara Elektronik

31 Ibid. 
diperbaiki. ${ }^{32}$ Pemrakarsa menyampaikan kembali perbaikan dokumen ANDAL dan RKL-RPL sesuai dengan ketentuan dalam Peraturan Pemerintah Nomor 24 Tahun 2018 tentang Pelayanan Perizinan Berusaha Terintegrasi Secara Elektronik. ${ }^{33}$

Berdasarkan dokumen ANDAL dan RKL-RPL yang telah diperbaiki sebagaimana dimaksud, Komisi Penilai AMDAL melakukan penilaian akhir terhadap dokumen ANDAL dan RKL-RPL. ${ }^{34}$

Komisi Penilai AMDAL menyampaikan hasil penilaian akhir berupa rekomendasi hasil penilaian akhir kepada menteri yang menyelenggarakan urusan pemerintahan di bidang perlindungan dan pengelolaan lingkungan hidup, gubernur, atau bupati/wali kota sesuai kewenangannya. ${ }^{35}$

Menteri yang menyelenggarakan urusan pemerintahan di bidang perlindungan dan pengelolaan lingkungan hidup, gubernur, atau bupati/wali kota berdasarkan rekomendasi hasil penilaian sebagaimana dimaksud atau rekomendasi hasil penilaian akhir dari Komisi Penilai AMDAL sebagaimana dimaksud, menetapkan keputusan kelayakan lingkungan hidup atau ketidaklayakan lingkungan hidup. ${ }^{36}$ Penetapan keputusan kelayakan lingkungan hidup sebagaimana merupakan pemenuhan dokumen AMDAL. Penetapan keputusan ketidaklayakan lingkungan hidup merupakan kegagalan pemenuhan dokumen AMDAL dan Izin Lingkungan yang telah diterbitkan oleh Lembaga OSS. ${ }^{37}$

Dalam hal Pelaku Usaha dalam usaha dan/atau kegiatannya akan membangun pusat kegiatan, permukiman, dan infrastruktur yang akan menimbulkan gangguan keamanan, keselamatan, ketertiban, dan kelancaran lalu lintas dan angkutan jalan, penyusunan dokumen AMDAL atau UKL-UPL sekaligus dilakukan dengan penyusunan analisis dampak lalu lintas sesuai dengan ketentuan peraturan perundang-undangan di bidang lalu lintas dan angkutan jalan. ${ }^{38}$

Hasil analisis dampak lalu lintas sebagaimana dimaksud yang dimuat dalam AMDAL atau UKL-UPL merupakan hasil analisis dampak lalu lintas sebagaimana dimaksud dalam undang-undang di bidang lalu lintas dan angkutan jalan. ${ }^{39}$

\footnotetext{
32 Ibid.

${ }^{33}$ Pasal 59 Peraturan Pemerintah Nomor 24 Tahun 2018 tentang Pelayanan Perizinan Berusaha Terintegrasi Secara Elektronik

${ }^{34}$ Ibid.

35 Ibid.

${ }^{36}$ Pasal 60 Peraturan Pemerintah Nomor 24 Tahun 2018 tentang Pelayanan Perizinan Berusaha Terintegrasi Secara Elektronik

${ }^{37}$ Ibid.

${ }^{38}$ Pasal 62 Peraturan Pemerintah Nomor 24 Tahun 2018 tentang Pelayanan Perizinan Berusaha Terintegrasi Secara Elektronik

${ }^{39}$ Ibid.
} 
Dalam hal Pelaku Usaha memerlukan izin di bidang pengelolaan lingkungan hidup untuk kegiatan:40

a. Menghasilkan, mengangkut, mengedarkan, menyimpan, memanfaatkan, membuang, mengolah, dan/atau menimbun bahan berbahaya dan beracun dan penyusunan dokumen Amdal dilakukan termasuk pengelolaan limbah bahan berbahaya dan beracun;

b. Pembuangan air limbah ke laut;

c. Pembuangan air limbah ke sumber air; dan/atau

d. Memanfaatkan air limbah untuk aplikasi ke tanah,

Izin di bidang pengelolaan lingkungan hidup tersebut diintegrasikan ke dalam Izin Lingkungan. Pengintegrasian izin di bidang pengelolaan lingkungan hidup tersebut ke dalam Izin Lingkungan sebagaimana dimaksud dalam Pasal 63 dilakukan melalui:

a. Mekanisme penyusunan dan penilaian AMDAL atau UKL-UPL pada tahap perencanaan usaha dan/atau kegiatan; atau

b. Perubahan Izin Lingkungan.

Secara prosedural pengurusan dokumen AMDAL dan/atau UKL-UPL sebagian besar diadopsi melalui Peraturan Pemerintah Nomor 27 Tahun 2012 tentang Izin Lingkungan akan tetapi yang membedakan adalah pelaku usaha dapat mengantongi izin usaha dan izin lingkungan hanya didasarkan pada komitmen tanpa didahului dengan pengurusan dokumen AMDAL dan/atau UKL-UPL. Ketentuan ini menjadi persoalan dalam ruang lingkup normatif maupun empiris. Secara normatif Peraturan Pemerintah Nomor 24 Tahun 2018 tentang Pelayanan Perizinan Berusaha Terintegrasi Secara Elektronik jelas bertentangan dengan semangat UUPPLH yang menyatakan bahwa setiap usaha dan/atau kegiatan yang berdampak penting41 terhadap lingkungan hidup wajib memiliki Izin lingkungan yang berbasis AMDAL. Sedangkan secara empiris kerusakan lingkungan dapat saja terjadi karena pelaku usaha maupun masyarakat yang mungkin terdampak lingkungan belum dapat mengetahui dampak dari kegiatan usaha/kegiatan yang akan dijalankan oleh Pelaku usaha.

AMDAL dan/atau UKL-UPL seharusnya menjadi dokumen awal yang merupakan garda pertama untuk menyatakan bahwa pemilik perusahaan tersebut bersedia untuk melakukan pengelolaan terhadap lingkungan, kemudian pemerintah akan melakukan pemeriksaan dan evaluasi dalam jangka waktu tertentu. ${ }^{42}$

\footnotetext{
${ }^{40}$ Pasal 63 Peraturan Pemerintah Nomor 24 Tahun 2018 tentang Pelayanan Perizinan Berusaha Terintegrasi Secara Elektronik

41 Peraturan Menteri Lingkungan Hidup dan Kehutanan Republik Indonesia Nomor: P.38/MENLHK/SETJEN/KUM.1/7/2019 tentang Rencana Usaha dan/atau Kegiatan Yang Wajib Memiliki Analisis Dampak Lingkungan Hidup, dampak penting adalah perubahan lingkungan hidup yang sangat mendasar yang diakibatkan oleh suatu Usaha dan/atau Kegiatan.

42 Ibid.
} 


\subsubsection{AMDAL Sebagai Kelayakan Suatu Kegiatan Usaha}

Pertanyaan terkait kelayakan lingkungan dalam dokumen AMDAL terkait fungsinya sebagai instrumen pencegahan penceraman dan/atau perusakan lingkungan hidup adalah saat AMDAL akan memerankan fungsinya tersebut.

Ketika dokumen AMDAL secara subtantif (kelayakan lingkungan) dinyatakan tidak layak lingkungan berarti dokumen tersebut tidak disetujui yang otomatis tidak mungkin diajukan permohonan izin lingkungan oleh karena itu seharusnya tidak akan ada izin usaha atau kegiatan, dengan demikian tidak terjadi dampak lingkungan baik pencemaran dan/atau kerusakan lingkungan hidup, atau jika kemudian dokumen AMDAL tersebut disetujui peran AMDAL sebagai instrumen pencegahan pencematan dan/atau kerusakan lingkungan hidup adalah adanya kajian dampak lingkungan yang telah diprediksi dalam dokumen AMDAL dalam pelaksanaanya sudah dapat diantisipasi dan dapat diminimalisir sepanjang ambang batas atau buku mutu atau kriteria baku kerusakan lingkungan hidup.

\subsubsection{Penegakan Hukum Dalam Pelaksanaan AMDAL}

Undang-Undang Nomor 32 Tahun 2009 menyediakan tiga macam penegakan hukum lingkungan yaitu penegakan hukum administrasi, perdata dan pidana. Di antara ketiga bentuk penegakan hukum yang tersedia, penegakan hukum administrasi dianggap sebagai upaya penegakan hukum terpenting. Hal ini karena penegakan hukum administrasi lebih ditunjukan kepada upaya mencegah terjadinya pencemaran dan perusakan lingkungan. Di samping itu, penegakan hukum administrasi juga bertujuan untuk menghukum pelaku pencemaran dan perusakan lingkungan. ${ }^{43}$

Penegakan hukum administratif pada dasarnya diatur dalam UndangUndang Nomor 32 Tahun 2009 yakni melalui cara preventif dalam perlindungan dan pengelolaan lingkungan hidup. Ada beberapa macam sanksi administratif yang biasa diberlakukan terhadap pelanggaran yang dilakukan oleh pelaku yaitu:

a. Bestuurdwang (paksaan pemerintah);

b. Penarikan kembali keputusan yang menguntungkan (izin, subsidi, pembayaran dan sebagainya);

c. Pengenaan uang paksa oleh pemerintah (dwangsom);

d. Pengenaan denda administratif (administrative boeto).

${ }^{43}$ Ibid. 
Penegakan lingkungan administratif berupa pengawasan dan sanksi administratif dalam UUPPLH telah diatur dalam BAB XII bagian kedua meliputi Pasal 76 sampai dengan Pasal 83 UUPPLH, sebagai berikut: Pasal 76 Menteri, Gubernur, atau Bupati/Walikota menerapkan sanksi administratif kepada penanggung jawab usaha dan/atau kegiatan jika dalam pengawasan ditemukan pelanggaran terhadap izin lingkungan.

(1) Sanksi administratif terdiri atas:

a. Terguran terulis;

b. Paksaan pemerintah;

c. Pembekuan izin lingkungan; atau

d. Pencabutan izin lingkungan.

Kumulatif Penerapan sanksi administratif secara kumulatif terdiri atas kumulatif internal dan kumulatif eksternal. Kumulatif internal adalah penerapan sanksi yang dilakukan dengan menggabungkan beberapa jenis sanksi administratif pada satu pelanggaran. Misalnya sanksi paksaan pemerintah digabungkan dengan sanksi pembekuan izin. Kumulatif ekternal adalah penerapan sanksi yang di lakukan dengan menggabungkan penerapan salah satu jenis sanksi administratif dengan penerapan sanksi lainnya, misalnya sanksi pidana. ${ }^{44}$

Selain ketentuan administratif, ketentuan hukum perdata juga diatur didalam Pasal 84 UUPLH yang menyatakan:

(1) Penyelesaian sengketa lingkungan hidup dapat ditempuh melalui pengadilan atau diluar pengadilan;

(2) Pilihan penyelesaian sengketa lingkungan hidup dilakukan secara sukarela oleh para pihak yang bersengketa;

(3) Gugatan melalui pengadilan hanya dapat ditempuh apabila upaya penyelesaian sengketa di luar pengadilan yang dipilih dinyatakan tidak berhasil oleh salah satu atau para pihak yang bersengketa.

UUPLH juga membuka celah adanya penyelesaian sengketa melalui jalur nonlitigasi atau penyelesaian sengketa di luar pengadilan.

Adapun tenggang waktu pengajuan gugatan diatur di dalam Pasal 89 UUPLH yang menyatakan:

(1) Tenggang kedaluwarsa untuk mengajukan gugatan ke pengadilan mengikuti tenggang waktu sebagaimana diatur dalam ketentuan Kitab Undang-Undang Hukum Perdata dan dihitung sejak diketahui adanya pencemaran dan/atau kerusakan lingkungan hidup;

${ }^{44}$ Ibid. 
(2) Ketentuan mengenai tenggang waktu kedaluwarsa tidak berlaku terhadap pencemaran dan/atau kerusakan lingkungan hidup yang diakibatkan oleh usaha dan/atau kegiatan yang menggunakan dan/atau mengelola B3 serta menghasilkan dan/atau mengelola limbah B3

Selanjutnya ketentuan hukum pidana sebagai ketentuan (ultimum remedium) diatur di dalam Pasal 97 hingga 120 BAB XV tentang Ketentuan Pidana.

\section{Kesimpulan}

Berdasarkan pada pembahasan di atas maka dapat disimpulkan bahwa kedudukan AMDAL dalam pengelolaan Lingkungan hidup sangat penting dan strategis karena merupakan instrumen pencegahan pencemaran lingkungan yang menentukan mutu lingkuangan melalui mekanisme pengujian dokumen seperti AMDAL dan UKL-UPL. Selanjutnya penerapan AMDAL juga menjadi sistem yang menjaga stabilitas tujuan perusahaan;

Penyimpangan terhadap prosedur penerapan AMDAL sebagai syarat perizinan memiliki mekanisme penegakan hukum yaitu penegakan hukum administrasi, perdata dan pidana. Di antara ketiga bentuk penegakan hukum yang tersedia, penegakan hukum administrasi dianggap sebagai upaya penegakan hukum terpenting. Hal ini karena penegakan hukum administrasi lebih ditunjukan kepada upaya mencegah terjadinya pencemaran dan perusakan lingkungan. Di samping itu, penegakan hukum administrasi juga bertujuan untuk menghukum pelaku pencemaran dan perusakan lingkungan.

\section{Daftar Pustaka}

\section{Buku \& Jurnal}

Amiruddin \& Asikin H. Zainal. (2003), Pengantar Metode Penelitian Hukum. Jakarta: Raja Grafindo Persada

Danusaputro, St. (1998). Hukum Lingkungan. Bandung: Buku I Bina Cipta.

Mutiara, P. S. (n.d.). Analisis Dampak Lingkungan.

ND, Mukti. Fajar., \& Yulianto Achmad. (2010). Dualisme Penelitian Hukum Normatif E Empiris. Yogyakarta: Pustaka Pelajar.

Marzuki Peter M, (2005), Penelitian Hukum Normatif, Jakarta: Kencana 
Rustamaji, Muhammad. (2017). Pilar-Pilar Hukum Progresif, Menyelami Pemikiran Satjipto Raharjo. Yogyakarta: Thafa Media.

Wignjosoebroto Soetandyo, (2013) Hukum, Konsep dan Metode, Malang: Setara Press

Silalahi, M. Daud., \& Kristianto. (2016). Perkembangan Pengaturan Amdal di Indonesia. Bandung: Keni Media.

Suharto, Edi. (2010). CSR \& Comdev Investasi Kreatif Perusahaan di Era Globalisasi. Bandung: Alfabeta.

Sukananda, Satria. (2019). Pertanggungjawaban Perusahaan Terhadap Tidak Terlaksananya Kewajiban Tanggung Jawab Sosial Perusahaan (Corporate Social Responsibility) di Indonesia. Yogyakarta: Tesis Program Pasca Sarjana Magister Ilmu Hukum Fakultas Hukum Universitas Islam Indonesia.

Suparni, N. (1994). Pelestarian Pengelolaan dan Penegakan Hukum Lingkungan. Jakarta: Sinar Grafika.

Taufiq, M. (September 2011). Kedudukan dan Prosedur Amdal Dalam Pengelolaan Lingkungan Hidup. Jurnal Wiga Vol. 2 No. 2, 1.

Wijoyo, S. (1999). Penyelesaian Sengketa Lingkungan. Surabaya: Airlangga University Press.

Yakin, S. K. ((Maret 2017)). Analisis Mengenai Dampai Lingkungan (AMDAL) Sebagai Instrumen Pencegahan Pencemaran dan Perusakan Lingkungan. Badamai Law Journal Vol. 2, Issues 1, 123.

\section{Peraturan Perundang-Undangan}

Undang-Undang Dasar Republik Indonesia Tahun 1945

Undang-Undang Nomor 4 Tahun 1982 tentang Ketentuan-Ketentuan Pokok Pengelolaan Lingkungan Hidup

UU No. 32 Tahun 2009 tentang Perlindungan dan Pengelolaan Lingkungan Hidup (UUPPLH) 
Peraturan Pemerintah Nomor 27 Tahun 2012 tentang Izin Lingkungan Peraturan Pemerintah Nomor 24 Tahun 2018 tentang Pelayanan Perizinan Berusaha Terintegrasi Secara Elektronik;

Peraturan Menteri Lingkungan Hidup dan Kehutanan Republik Indonesia Nomor: P.38/MENLHK/SETJEN/KUM.1/7/2019 tentang Rencana Usaha dan/atau Kegiatan Yang Wajib Memiliki Analisis Dampak Lingkungan Hidup. 